\title{
The Birth of International Conceptual History
}

\author{
JAN IFVERSEN
}

\begin{abstract}
In March 2020, Melvin Richter, one of the founders of international, conceptual history passed away. This sad occasion makes it timely in our journal to reflect on the process that turned national projects within conceptual and intellectual history into an international and transnational enterprise. The text that follows-published in two parts, here and in the next issue-takes a closer look at the intellectual processes that led up to the founding meeting of the association behind our journal, the History of Concepts Group. It follows in the footsteps of Melvin Richter to examine the different encounters, debates and protagonists in the story of international, conceptual history. The text traces the different approaches that were brought to the fore and particularly looks at Melvin Richter's efforts to bridge between an Anglophone tradition of intellectual history and a German tradition of Begriffsgeschichte.
\end{abstract}

\section{KEYWORDS}

basic concepts, Begriffsgeschichte, Cambridge school, historical semantics, language, rhetoric, speech acts

In this text, I will take a look at the beginnings of the international collaboration on conceptual history that led to the international association, History of Concepts Group (HCG), to yearly international conferences, to doctoral training courses and not least to our journal, Contributions to the History of Concepts. The purpose is to follow closely the debates and the activities that lead to the bridging of several national approaches within a conceptual history strongly influenced by the linguistic turn. I deal with the beginning of this collective égo-histoire in two parts. In the first part, I tell the story of bridging projects up to the foundational meeting in London in 1998. In the second part, I examine the role of some important figures in fusing conceptual history into an independent, international contribution to intellectual history.

\section{Melvin Richter: The Master Builder}

The idea of taking a look back was prompted by a sad event. On 14 March 2020, one of the founding figures of HCG, Melvin Richter passed away 
just before his ninety-ninth birthday. Melvin Richter played a leading role in bringing different strands of historiography and political theory into an intellectual fusion. He chose German Begriffsgeschichte (BG) invented by Reinhart Koselleck as the igniter of the fusion. Melvin Richter had already made his mark as a historian of political thought solidly anchored in historical contextualism. In the early 1980s, he accidently encountered BG during a research stay at the Herzog August Bibliothek in Wolfenbüttel. As he states in an interview in Contributions, he one day picked up the first volume of the famous magnum opus of BG, Geschichtliche Grundbegriffe (GG), the eight-volume lexicon on basic concepts in German history. ${ }^{1}$ This was a fateful action. During his stay in Germany, he was invited to speak in Reinhart Koselleck's famous colloquium at Bielefeld University. He also met with the younger generation of conceptual historians such as Hans Erich Bödeker and Lucian Hölscher. Richter first presented the GG to American readership in a 1986 article in Political Theory. ${ }^{2}$ In a series of articles in leading intellectual history journals, he launched the idea of bridging BG with the Anglophone tradition of intellectual history around the so-called Cambridge school. ${ }^{3}$ Richter himself was already friends with leading figures of this school such as John Pocock and Quentin Skinner, but he also extended his network within BG in Germany as well as in other European countries. In 1988, Professor Kari Palonen invited him to give a talk in Finland, one of the hotbeds of conceptual history outside Germany. ${ }^{4}$ We will return to Palonen in a moment. In 1991, Richter gave a paper on BG in theory and practice at a conference on Main Trends in Cultural History at the Huizinga Institute in the Netherlands. Among the invited speakers were Koselleck and Skinner. ${ }^{5}$ The conference was organized by a new generation of Dutch conceptual historians, among whom were Wyger Velema and Pim den Boer who were to become main figures in a large project on Dutch conceptual history and international, conceptual history. The organizers' call for a more thorough reflection of the role of language in cultural history, however, did not lead to any rapprochement among the contributors. In his contribution, Kosel-

1. Melvin Richter, Vicente Oieni, and João Feres Júnior, "Conceptual History and Translation: An Interview with Melvin Richter," Contributions to the History of Concepts 4, no. 2 (2008): 226-238.

2. Melvin Richter, "Conceptual History (Begriffsgeschichte) and Political Theory," Political Theory 14, no. 4 (1986): 604-637.

3. For the origin of the term "Cambridge School," see Samuel James, "J.G.A. Pocock and the Idea of the "Cambridge School' in the History of Political Thought," History of European Ideas 45, no. 1 (2019): 83-98, https://doi.org/10.1080/01916599.2018.1498011.

4. Personal communication with Kari Palonen, mail, 3 June 2020.

5. Willem Melching and Wyger Velema, eds., Main Trends in Cultural History: Ten Essays (Amsterdam: Rodopi 2004). 
leck hinted at the criticism against BG of reducing language to concepts, but he did not engage with other ways of studying language in history. Quentin Skinner simply began his contribution with a remark that the study of rhetoric opened a new door to cultural history and then immediately went on to present a first take on his many later works on Hobbes. Richter's own contribution was the only one that really tried to cross bridges. He continued to present the BG as expressed through the GG-and now with the inclusion of the Franco-German Project around the Handbuch politisch-sozialer Grundbegriffe in Frankreich 1680-1820 - as a good companion for the Cambridge school. Although this time, he had to include a caricature-like refutation of post-structuralism to underline his arguments for a contextualism along the line of Koselleck's social history. ${ }^{7}$

In December 1992, Melvin Richter co-organized a symposium at the German Historical Institute in Washington together with its director, Hartmut Lehmann to celebrate the publication of the seventh and last volume of the GG. Koselleck was invited to respond to comments on BG given by a group of intellectual historians, among them John Pocock. ${ }^{8}$ In his opening talk, Richter continuously argued for a synthesis of the two strands of intellectual history, the German and the English. Pocock explicitly took upon himself to answer a set of questions posed to him by Richter on conceptual history. The answers did not, however, really support the symbiotic thinking proposed by Richter. In fact, Pocock was overtly critical of the fragmentary and overdetermined approach he detected in conceptual history, though based solely on Richter's presentation since he did not read German (and had not looked into the English translations of Koselleck's work). ${ }^{9}$ Pocock was more than skeptical of carving concepts out of languages with its armature of vocabularies, grammars, and rhetorics. Even if he accepted that long-term, diachronic studies of language could be conducted, he feared that the focus on language as a resource determining practices would neglect the performative aspect of language. He was afraid that this would lead to a re-

6. The first volume was published in 1985, Rolf Reichardt and Eberhard Schmitt, eds., Handbuch politisch-sozialer Grundbegriffe in Frankreich 1680-1820 (Munich: R. Oldenbourg Verlag, 1985). Melvin Richter already discussed the Handbuch as part of German conceptual history in 1987, Melvin Richter, "Begriffsgeschichte and the History of Ideas," Journal of the History of Ideas 48, no. 2 (1987): 247-263, https://doi.org/10.2307/2709557.

7. Melvin Richter, "Reconstructing the History of Political Languages: Pocock, Skinner, and the Geschichtliche Grundbegriffe," History and Theory 29, no. 1 (1990): 38-70, https://doi.org/10.2307/2505203.

8. Hartmut Lehmann and Melvin Richter, eds., The Meaning of Historical Terms and Concepts (Washington, DC: German Historical Institute, 1996).

9. Several of Koselleck's texts were available in English, including the books Vergangene Zukunft: Zur Semantik geschichtlicher Zeiten translated in 1985 by Keith Tribe and Kritik und Krise translated in 1988. 
ductionism, which would not take into account what language users do with and to language. In his view, a history of linguistic change could only be a history of "things done with language." ${ }^{10}$ His privileging of speech acts and arguments as the scenes of change led him to reduce conceptual history to an ancillary or a supplement that could help to provide information about the layers of discursive resources. Even that in the end would entail a risk of trapping the historian in anachronistic claims about the existence of basic concepts that the historical actors did not use. Finally, Pocock also had problems accepting the basic idea of an increased and intense period of conceptual change, a Sattelzeit that heralded our modern societies, and preferred to see all change as a continuous confrontation and mixing of discourses within specific communities of language or culture. The latter also led him to dismiss the ideas endorsed by Richter of comparing histories and searching for transnational influences.

Koselleck mainly directed his response to Pocock's criticism, which, although formulated in Oxbridge gentleman-style, raised fundamental doubts about BG. Koselleck certainly accepted the premise that concepts only emerged in specific language use and could not be studied as free-floating or autonomous units. With a slightly ironic posture, he consented to what he termed Pocock's and Skinner's "rigorous historicism," where concepts appear as singular events through speech acts. On the other hand, he immediately added a sociological dimension to this historicism. Where Pocock and Skinner opted for a micro-interpretation of the contexts around individual speech acts, Koselleck argued for the continuities created by the processes of reconceptualization and recycling of concepts. He thus elegantly shifted the weight from the individual user-perspective to the continuities upheld by the corpus of language with its stock of concepts that users draw from in their recycling. In fact, he turned upside down Pocock's argument about the study of continuities being simply a supplement to understanding the intentional interventions of language users. For Koselleck, the study of change had to depart from a structural perspective in the long-term processes of change and continuity within the corpus of languages and beyond.

Koselleck did not explicitly confront Pocock's criticism of reducing language to concepts. He could have insisted on the structural semantics-the linguistic triangle of concepts, words, and objects that undergirds his theory of language - to counter Pocock's rather broad understanding of language. ${ }^{11}$ Instead, he chose to focus on the main hypothesis of BG, namely the role of basic concepts. With his theory of basic concepts, Koselleck is able to

10. Lehmann and Richter, The Meaning, 54.

11. For a presentation of Koselleck's theory of language, see Jan Ifversen, "Key Concepts and How to Study Them," Contributions to the History of Concepts 6, no. 1 (2011): 63-86, https://doi.org/10.3167/choc.2011.060104. 
combine a focus on language use or conceptualization (concepts become a basic element of the political and social vocabulary) with a language theory (concepts are the pivots of discourse) and a structural perspective (the repeatable structures stored in language).$^{12}$ It is the latter perspective that finally allows Koselleck to distance himself from what he considers a simple registering "of unique speech acts within specific situations" (the rigorous historicism) and claim that basic concepts take on lives of their own. ${ }^{13}$

Already in the opening of his text, Koselleck in passing lit the fuse that would detonate the crucial disagreement with Pocock and Skinner, when he reiterated what has become the doxa of BG, namely that concepts are both indicators and factors of change. Concepts as factors could-to some degree at least-fit Pocock's emphasis on language use. When concepts are treated as indicators, the action is deferred to another sphere that Koselleck here terms extra-linguistic forces. ${ }^{14}$ This two-dimensional history of both concepts (stored and used) and of extra-linguistic forces demarcate the differences. Pocock's limited contextualism is a far cry from BG's social history needed to make concepts indicators of changes taking place somewhere else. Whether Koselleck was simply extending his contextualism to include larger and more long-lasting contexts or he was, in fact, presenting an argument of ontological range about the world outside language, contextualism had already been a topic in intra-German scholarly debates on BG. The two-dimensional history, however, clearly demonstrated that Pocock's history of political thought and BG were not exactly on the same wavelength. The aforementioned was preoccupied with reconstructing the discursive contexts of specific language users, while the latter extracted the emergence of basic concepts from the full range of usages "specific to a given period or social stratum." 15

Perhaps Koselleck ran out of steam, but he did not spend any energy on refuting Pocock's criticism of the modernity hypothesis (the Sattelzeit) behind the GG, perhaps for the simple reason that it would always be countered with examples of other threshold periods. Instead, he discarded Pocock's methodological nationalism (each culture having its discourses and threshold periods) and argued for a comparative history of concepts in line with the studies of the middle class conducted by his own research group (among whom we find a young Willibald Steinmetz) in Bielefeld and of transnational

12. Koselleck's theory of basic concepts is at some points similar to the nodal points, empty and floating signifiers at the core of Ernesto Laclau and Chantal Mouffe's discourse theory, Ernesto Laclau and Chantal Mouffe, Hegemony and Socialist Strategy: Towards a Radical Democratic Politics (London: Verso, 1985).

13. Lehmann and Richter, The Meaning, 66.

14. Ibid., 67.

15. Ibid., 65. 
studies of concepts moving between speech communities. The latter would in fact later open a new horizon of expectation for international BG.

\section{New Efforts at Bridging}

This first crossfire between BG and the Cambridge school clearly demonstrated that Melvin Richter's continuous efforts to promote dialogue was not endorsed by the main proponents. Either they simply appeared in the same edited volumes under the loose umbrella of the linguistic turn, or they shared common enemies (the traditional history of ideas and the ahistorical political philosophy). Richter was still convinced that Anglophone intellectual history, including his own work, would gain from the broader historical agenda, the methodological rigor of historical semantics, and the theory of basic concepts. Therefore, he did not lose hope in his bridging project and turned his several articles into a book with a title welcoming BG, The History of Political and Social Concepts, even if the subtitle was "A Critical Introduction." ${ }^{16}$ The acknowledgements almost resembled a who's who in European and American intellectual history. In the book, Richter adds more detailed presentations of the actual studies in the three lexicons that he appoints to embody three different versions of BG, the Historisches Wörterbuch der Philosophie, the GG, and the Handbuch. What stands out in his presentation of GG is the emphasis on two aspects: the method of historical semantics and the modernity hypothesis. Richter spends quite a few pages in reconstructing Koselleck's venturing into semantics, and he equally emphasizes the hypothesis of the general, conceptual changes forming the Sattelzeit. Although social history is given importance in the genealogy that he provides for Koselleck's thinking, he is less interested in exploring the socalled synthesis between conceptual history and social history. ${ }^{17}$ The same is true for Koselleck's theory of basic concepts, which admittedly does not fit neatly with linguistic semantics.

One of Richter's great merits is that he insisted on granting the Handbuch project developed by Rolf Reichardt independent status in his introduction to BG. Being a more historical project, navigating between a history of mentality, a sociology of knowledge, and a rigid methodology of close se-

16. Melvin Richter, The History of Political and Social Concepts: A Critical Introduction (Oxford: Oxford University Press, 1995).

17. It is also worth noting that Richter in his genealogy of Koselleck's conceptual history dramatically downplayed the role of Carl Schmitt. For the important role that Schmitt played not only for Koselleck's modernity critique, but also for his conceptual history, see Niklas Olsen, History in the Plural: An Introduction to the Work of Reinhart Koselleck (New York: Berghahn, 2014). 
mantic studies, this project was much further away from Richter's own home turf, the history of political thought. Of the three elements mentioned, Richter chooses to highlight the Handbuch's link to the French tradition of studying mentalities, although without buying into the decanonizing of sources entailed in replacing thought with mentality. He still insists on the need to climb the peaks (or canons) of political thought. He also gives some credit to Reichardt's methodological refinements of historical semantics and follows him in discarding the interdisciplinary collaboration between linguists and historians around lexicometrie-with the first use of digital tools-as a simple curiosity. Despite this more than skeptical attitude, which in the case of Richter certainly had to do with his rather patronizing attitude (which he shared with many of his colleagues) toward everything poststructuralist, representatives of this approach were to participate in the internationalization of conceptual history.

To legitimate bringing BG to the table and to prepare the bridging, Richter makes an effort to search for and arrange the connecting points in his reading of the Cambridge School. In his version of Pocock and Skinner, the emphasis is on the "linguistic limitations" of the historical language users. ${ }^{18}$ He accentuates their contextualism at the expense of agency and intentionality. Furthermore, he contrasts their looser handling of language-which in Pocock's case serves as metaphor rather than theory-with the systematic, historical semantics of BG. Pocock has not "developed a systematic method, and Skinner might have underestimated the importance of conceptual vocabularies, but seems to move more toward "his own version of conceptual history." With this conceptual "softening," Richter makes an effort to get around Skinner's quite explicit statements about the impossibility of separating the meaning of a concept from the speech acts in which it operates and thus the futility of doing a history of only concepts. Finally, Richter recommended that Pocock and Skinner add a broader context to their contextualism, a greater sensitivity to reception, and a heightened focus on how contestations included collective identities. Even if Skinner was quite adamant in replying to his critics, one can have doubts about whether he would feel comfortable in Richter's redescription. To my knowledge, Pocock's engagement with BG was a once in a lifetime experience.

\section{The Second Father}

The debate about bringing BG into the international orbit of intellectual history began to involve a greater audience of scholars. Kari Palonen played

18. Richter, The History, 126. 
a leading role in introducing BG to Finnish academia and from very early on conducted an enterprise parallel to Richter's. Although well acquainted with BG and the Cambridge school since the mid-1980s, he began seriously working on joining conceptual history with Skinner's study of rhetoric from the early 1990s. In 1994, he published a manifesto-like text on conceptual history, into which he integrated Koselleck, Skinner, and Pocock. ${ }^{19}$ In his reading, all three represented variants of a conceptual history of political thought. What brought them together was an understanding that language was not a prison, but a scene-a Spielraum-for political action. With an actionist perspective drawn from Max Weber, he compared political thought to the rationality driving action. In fact, he viewed language as part of political action.

In order to make action and thus language use the overarching structure for conceptual history, he begins building a bridge from the opposite shore of Richter. According to Palonen, Pocock's reference to language was indeed to be understood as deliberately loose and in no way comparable to a structuralist understanding, which he simply dismissed-together with its postructuralist rethinking-as a determinist wiseacre approach. Following Pocock, he made contingency and not structure a key aspect of conceptual history. With his emphasis on rhetoric, Skinner pointed toward a radicalization of BG that Palonen intended to pursue. Due to their political nature, concepts would always be contingent and contested. They would always lead to different interpretations or what he calls "conceptions." ${ }^{20}$ To perform this radicalization, Palonen presented a very different reading of $B G$ than the one endorsed by Richter. First of all, he had to "de-sociologize" BG and reinterpret the links to social history in such a way that the context in need of reconstruction would only be one directly pointing back to the one activated in language use. The reality that Koselleck often referred to the extra-linguistic would in Palonen's adoption of BG only be linked to the referentiality articulated in language use. Therefore, concepts could not be understood as indicators of change as Koselleck claimed because he was committed to "a kind of sociologistic language," and a problematic, "realistic ontology" could be avoided. ${ }^{21}$ Second, Palonen severs the ties connecting historical semantics to linguistics. According to Palonen, the concept is not a linguistic term only linked to words. In his nominalist approach, it is a name for a knot of questions that scripts political action. In contrast to Richter, he thus makes Koselleck's theory of basic concepts the central aspect of BG. For this reason, he can easily dismiss the critique often raised that concepts are but one

19. Kari Palonen, Politics, Rhetoric and Conceptual History: Studies on Modern Languages of Political Theory (Jyväskylä: University of Jyväskylä, 1994).

20. Palonen, Politics, 11.

21. Ibid., 23. 
of several units in language. Even if concepts are expressed in vocabularies and context-oriented, they are something else, namely drivers of political action. To bring home his version of BG, he adopts Skinner's mantra that meaning, including concepts, only make sense in use. Concepts cannot be viewed as independent factors to be studied, for instance, as semantic layers with histories of their own.

In a short, but very dense text published in 1997, Palonen intensified his engagement with BG that he some years before had appointed as his home turf: "BG à la Koselleck is close to my approach." ${ }^{22}$ He laid out the different components or "layers" in the edifice of BG. The most important were the two theories of change, the micro and the macro theory. With the micro theory, Palonen is more open to the role of historical semantics in studying conceptual change. While he reiterates his point about concepts being problem knots, their changes also have to be understood as taking place within the linguistic triangle (of concepts, words, and reference). ${ }^{23}$ Of more importance is, however, the macro theory of change, which connects Koselleck's theory of temporality, that is, of both thresholds of change (Sattelzeit) and of temporal experience with action. The emptying or generalization of concepts with modernity goes hand in hand with a constant temporal orientation of concepts. For Palonen, this uncertainty and instability is precisely what makes them political (and what makes the political in its modern form emerge). The macro theory is for Palonen the glue that binds together the constant movement of concepts produced by language use and the historical movement set in motion by modernity. ${ }^{24}$

Palonen and Richter were both building bridges, but in very different ways. Richter tried to push the Cambridge School in a more contextualist and more methodological direction with a strong dose of historical semantics. Palonen, on the other hand, tried to sever the ties to linguistics and see concepts as essential parts of action in line with Skinner's particular insistence on rhetoric. Richter preferred to interpret the Sattelzeit hypothesis as a convenient-and also conventional-theory of modernity. Palonen insisted on seeing this hypothesis as linked to Koselleck's larger theory of temporal

22. Ibid., 22.

23. Kari Palonen, "An Application of Conceptual History to Itself: From Method to Theory in Koselleck's Begriffsgeschichte," Finnish Yearbook Political Thought 1 (1997): 39-69. For the importance of the linguistic triangle in BG, see Jan Ifversen, "Conceptual History: The History of Basic Concepts," in The Routledge Handbook of Language and Politics, ed. R. Wodak and B. Forchtner (London: Routledge, 2017), 122-134.

24. Palonen assembled his reflections on synergies between Skinner and Koselleck in Kari Palonen, Die Entzauberung der Begriffe: Das Umschreiben der politischen Begriffe bei Quentin Skinner und Reinhart Koselleck [The disenchantment of concepts: The rewriting of political concepts in Quentin Skinner and Reinhart Koselleck] (Münster: LIT Verlag, 2004). 
experience. Finally, Richter used social history to extend the contextualism of the Cambridge School, whereas Palonen downgraded the importance of adding it to BG. As we shall see, Richter and Palonen would soon be collaborating in setting the scene for an internationalization of BG. However, they would also come to represent two of the poles in the debates that emerged on this scene.

\section{More Bridge Builders}

The Netherlands was another hotspot for promoting dialogue between BG and Anglophone variants of intellectual history. A project entitled History of Concepts: Comparative Studies had been launched in 1994 under the auspices of the Institute for Advanced Studies in the Humanities and Social Sciences. In 1998, two Dutch historians, Karen Tilmans and Frank de Vree, edited a book together with the founder of the Journal of Political Thought, Iain Hampsher-Monk, with contributions from a wide range of international intellectual historians who had visited the Institute. ${ }^{25}$ Several of the contributors explicitly tried to locate themselves on the common scene of conceptual history. The results of these efforts were, however, meager.

The representatives of the Anglophone camp sharpened the criticism already articulated by Pocock. The editor, Iain Hampsher-Monk, simply discarded the idea that concepts could be indicators of larger social changes and took a clear constructivist stand. Social and political changes could only be seen as linguistic. Consequently, political actions could only be conceived as linguistic actions. Beyond politics and language there is only naked power and death. In his epilogue, Martin Van Gelderen drove another nail in the coffin of social history with his rallying cry that "the history of language subsumes social and political history."26 They also agreed that concepts could not be studied independently of their linguistic constellations. Where Richter and Palonen had engaged in a reconstruction of the analytical strategies of historical semantics, van Gelderen just reduced it to a methodological hodgepodge. Finally, as the icing on the cake, we are told that concepts could only be meaningful in action, which involves speakers and arguments. Even if Terence Ball, the American in the Anglophone camp, had chosen to ride under the banner of critical, conceptual history, and showed more openness to seeing concepts as the pivots of political language, he still viewed his approach as a history of arguments where things were done to language. ${ }^{27}$

25. Iain Hampsher-Monk, Karin Tilmans, and Frank de Vrees, eds. History of Concepts: Comparative Perspectives (Amsterdam: Amsterdam University Press, 1998).

26. Ibid., 232.

27. Ibid., 86. 
Hans Eric Bödeker, a long-term collaborator with Koselleck and a contributor to the GG, introduced the internal German debate on BG to the discussion. His contribution is particularly interesting because it draws out and elaborates on Koselleck's theory of the concept or his concept of the concept as this problem would be termed within international conceptual history. To develop his argument, Bödeker takes a detour into the longstanding German discussion instigated by Koselleck between himself and German linguists on the linguistic status of BG. ${ }^{28}$ As shown poignantly by Bödeker, Koselleck's understanding of the concept does not exactly match the conventional doxa on the relation between signifier and signified within linguistic semantics. Instead of simply deploring this, he proposes a different reading. While BG still departs from historical semantics in setting a linguistic context for meaning, the crucial elements are those basic concepts that must be understood as categories "that conceive cognitive achievements in linguistic acts of communication." ${ }^{29}$ Concepts thus do not just represent and refer to social phenomena; they cope with them. To be true to another of Bödeker's remarkable clarifications, they are used by the historical actors in coping with problems. With this reading of basic concepts, he approaches Palonen's understanding of concepts as problem knots. Furthermore, he neatly circumvents previous criticisms of $\mathrm{BG}$ for being too little oriented toward language use. As Bödeker elegantly remarks, concepts do not move, they are moved. He makes clear that BG was from the beginning focused on the pragmatic function of concepts and particularly the function of marking horizons of expectation. The function will have to be played out linguistically in acts of communication. Bödeker also confronted the charges raised against BG that the need for a social history with its extralinguistic reality would lead into a problematic realistic ontology. Instead of viewing concepts in the duality of indicators (referring to objects) and factors (stating objects), he emphasizes another important epistemological dimension of BG-the discrepancy and tension between meaning and object. Language certainly makes our experiences possible, but it also forms them in ways that do not capture everything in the real world. As Bödeker demonstrates, BG is also a historical investigation of the discrepancy between concepts and objects, between conceptual engineering and mastery on one hand, and on the gaps in this effort on the other hand. This point made by Bödeker was, however, not really taken up by other commentators until much later.

As the edited book showed, the main discussion around BG concentrated on the balance to be drawn between the different understandings of language: language as context, language as meaning (e.g., historical seman-

28. For a short overview of this debate, see Ifversen, Key Concepts.

29. Hampsher-Monk et al., History of Concepts, 58. 
tics and concepts) and language as communication. Most of the commentators brought in as representatives of the Anglophone approach did not buy into the larger contextual framing proposed by BG nor did they accept going down the road of a more detailed study of semantics.

\section{At the Margins}

Melvin Richter had included the other German version of BG developed by Rolf Reichardt and Hans-Jürgen Lüsebrink around the Handbuch project in his introduction. Reichardt published his own BG manifesto in the first volume of the Handbuch from 1985. The Handbuch project was conceived as a critique and an elaboration of Koselleck's BG, and Reichardt had already crossed swords with Koselleck, most notably around the French Revolution such as in the workshop organized at the famous Zentrum in Bielefeld in 1985. ${ }^{30}$ Reichardt and Lüsebrink also had their own bridging agenda. In 1998, Reichardt edited an international encounter-figuring his compagnon de voyage Hans-Jürgen Lüsebrink and the two Dutch historians, Wyger Velema and Pim den Boer, who had already played a leading role in the internationalization of BG-around historical semantics. ${ }^{31}$ In his introductory remarks, Reichardt broadened the arena of discussion to include French approaches. He agreed with the Anglophone approach that BG should strengthen the focus on communication, but with more weight on the reception part. He placed his own version of BG strongly within historical semantics, but argued for more methodological rigor borrowing from the French approach to discourse analysis. Working on discourse the French way allowed for a focused analysis of linguistic features in text corpora in order to identify the larger discursive patterns. The "microscopic" examination should be conducted with the help of the first generation of computerized methods (lexicométrie). Reichardt credited Jacques Guilhaumou, whom we will return to in the second part (to be published in the next issue of Contributions), with developing a historical discourse approach drawing on a more refined linguistic discourse analysis. ${ }^{32}$ Without taking a pre-digital turn, Reichardt and

30. Reinhart Koselleck and Rolf Reichardt, eds., Die Französische Revolution als Bruch des Gesellschaftlichen Bewußtseins [The French Revolution as a break in social consciousness] (Munich: Oldenburg, 1988).

31. Rolf Reichardt, ed., Aufklärung und historische Semantik: interdisziplinäre Beiträge zur westeuropäischen Kulturgeschichte [Enlightenment and historical semantics: Interdisciplinary contributions to Western European cultural history] (Berlin: Duncker \& Humblot, 1998).

32. This method emerged out of the interdisciplinary collaboration of linguists and historians at the laboratory at ENS in St. Cloud. For an overview of this approach, see 
Lüsebrink drew inspiration from this approach to refine their own version of discourse semantics, which, based on series of sources, would investigate the semantic nets-with their paradigmatic and syntagmatic relations-of particular lead words. These lead words could be seen as a methodological conversion of the basic concepts. All this would serve the main purpose of developing a historical semantic with a strong sociological orientation that both included everyday experiences or mentalities and a diversified view on difference when it came to areas of practice and social groups. It was no doubt the latter that separated the Handbuch project most from intellectual history and placed it closer to cultural history and histoire des mentalités. While it was methodologically ambitious and empirically well grounded (with twenty-two volumes published so far), it stayed more marginal within the different bridge-building efforts. There are probably several reasons for this. For one, it was a more specialized project around the French Revolution. Furthermore, its proximity to a broader cultural history distanced it from the agenda of intellectual history. Finally, its leading figures chose not to engage with the Richter-Palonen project of creating an international scene.

\section{Coming to the Meeting}

The first idea of a larger international meeting of different national projects around BG was conceived in Finland by the two leading figures in developing conceptual history in Finland-Henrik Stenius and Kari Palonen. Koselleck had visited both Finland in 1988 and Sweden in 1992. Stenius had organized a Nordic Network of conceptual history with the Gothenburg-based Swedish historian Bo Stråth in the early 1990s. Palonen got in touch with Melvin Richter about the idea and discussed it with him in more detail during a visit to New York in February $1997 .{ }^{33}$ Already when Stenius was appointed director of the Finnish Institute in London in the autumn of 1996, it was decided that this would be the obvious place to host the event. ${ }^{34}$ In August, Richter and Palonen sent out a call for a meeting to a number of scholars identified as having a stake in national projects on conceptual history. The purpose of the meeting was to present these and other projects and discuss the feasibility of comparison. ${ }^{35}$ The meeting took place in London $18-20$ June and was

Jan Ifversen, "Jacques Guilhaumou and the French School," Redescriptions: Yearbook of Political Thought, Conceptual History and Feminist Theory 12 (2009): 244-261.

33. Personal communication with Kari Palonen, mail, 3 June 2020.

34. Interview with Henrik Stenius, 18 January 2021.

35. Richter and Palonen, Meeting Proposal: Conceptual Changes in European Political Cultures, August 1997. 
attended by twenty-nine scholars from fourteen countries. The main event was a panel debate between Reinhart Koselleck and Quentin Skinner.

Several of the participants had already been involved in bridging BG with similar approaches under the general umbrella of the linguistic turn. They were already engaged in local projects. The first issue of the newsletter that was one of the immediate results of the meeting contained reports from projects in the Netherlands, Russia, Denmark, Finland, and France. ${ }^{36}$

Allow me as an eyewitness to give a more personal report on my way to the London meeting. I attended it together with two colleagues from Denmark, the political scientists Uffe Jacobsen and Tina Lahogue (now Pipa). My own linguistic turn arose from French poststructuralist thinking, but I became acquainted with BG in the early 1990s. In 1994, fellow historian Uffe Østergård and I set up a Danish network of conceptual history with a grant from the Danish Research Council. From 1994 to 1997, the network published conceptual history articles and organized workshops among which was an international workshop on Conceptual History between Language, History and Ideas in May 1995 attended by Danish and international scholars including the French historian Sophie Wahnich, who represented the French approach to concepts and discourse analysis. ${ }^{37}$ In 1996, we invited Hans-Jürgen Lüsebrink to Aarhus as a guest professor. Other national projects, such as the Dutch, Finnish, and French were, however, much further ahead in pursuing studies of concepts in their national languages. ${ }^{38}$

No written sources are left from the most-hyped event at the meeting, the debate between the two titans around which the entire bridging operation was framed. It was undertaken in a very polite atmosphere with the more jovial Reinhart Koselleck responding to the standard criticism of BG's linguistic myopia that Quentin Skinner formulated in a rhetorically elegant way. The debate left the impression that the bridge to be created would be without the involvement of these two pillars. Those of us who attended the meeting will, however, remember the fantastic and exotic midsummer party hosted by Henrik Stenius and his wife Kerstin first in a pub rented for the occasion and then during the light midsummer night in the Steniuses' apartment just upstairs from the pub. When some of us younger scholars drove home in a taxi after having been marinated in Finnish culture, we decided

36. History of Concepts Newsletter 1, Fall 1998.

37. Jan Ifversen and Uffe Østergård, eds., Begreb \& Historie [Concept and history] (Aarhus: Center for Kulturforskning 1996).

38. I will say more about some of the national projects in part 2 when I deal with the main BG entrepreneurs in internationalizing BG. For the Dutch project, see the excellent overview in Karin Tilmans and Wyger Velema, "Applying Begriffsgeschichte to Dutch History: Some Remarks on the Practice and Future of a Project," Contributions to the History of Concepts 2, no. 1: 43-58. 
that we were about to become part of an international adventure. Next to me in the taxi was Martin Burke, a former student of Melvin Richter. I would become the first secretary of the new association, and Martin Burke would take over.

In part 2, I will look closer at the fusion effects created by some of the scholars that joined the association in its first years.

Jan Ifversen is director of the research program Uses of the Past and associate professor in European Studies at Aarhus University.

ORCID: 0000-0002-2572-1264.E-mail: jif@cas.au.dk 